\title{
Additions to the South African sea anemone (Cnidaria, Actiniaria) fauna, with expanded distributional ranges for known species
}

\author{
Megan C. Laird', Charles L. Griffiths' \\ I Department of Biological Sciences and Marine Research Institute, University of Cape Town \\ Corresponding author: Charles L. Griffiths (Charles.Griffiths@uct.ac.za)
}

Academic editor: Burgert Muller | Received 12 March 2016 | Accepted 12 March 2016 | Published 1 April 2016

http://zoobank.org/7E415182-627F-4F4E-A4F1-9140FF8126C9

Citation: Laird MC, Griffiths CL (2016) Additions to the South African sea anemone (Cnidaria, Actiniaria) fauna, with expanded distributional ranges for known species. African Invertebrates 57(1): 15-37. doi: 10.3897/afrinvertebr.57.8459

\begin{abstract}
The last monograph on South African sea anemones was published by Carlgren more than 75 years ago. Since that time, very little taxonomic research has been undertaken on this group and only seven additional species have been added to the regional fauna. In this study we document the history of taxonomic research and of species discovery for the South African anemone fauna, report on further additions to the fauna, and document expanded distributional ranges of known species. This study presents data from our own collections, as well as from the examination of historical data and museum collections, and from photographic records and specimens collected by SCUBA divers. Based on these data, two newly-discovered, but still un-described species, along with 12 new records, are added to the list of South African sea anemones. In addition, the ranges of 39 previously-known species are expanded. These new discoveries raise the total number of Actiniaria and Corallimorpharia species recognised from South African waters to 63.
\end{abstract}

\section{Keywords}

Anemone, Actiniaria, South Africa, species list

Copyright Megan C. Laird, Charles L. Griffiths. This is an open access article distributed under the terms of the Creative Commons Attribution License (CC BY 4.0), which permits unrestricted use, distribution, and reproduction in any medium, provided the original author and source are credited. 


\section{Introduction}

The first anemone record from South African waters was Actinia capensis in 1830, now accepted as Bunodosoma capense (Lesson, 1830). No further new discoveries that remain valid today were made until 1857, when Cystiactis reynaudi, now called Bunodactis reynaudi, was described from the Cape of Good Hope (Milne Edwards 1857). Verrill (1865, $1867,1869)$ then described three new species, now called Haloclava capensis, Corynactis annulata and Anthothoe stimpsonii. This was followed by the description of Anthopleura michaelseni by Pax (1926) and by the addition of 10 species collected during the German deep-sea expedition on the steamer "Valdivia" two years later (Carlgren 1928a). In 1938, Carlgren made what has been the most significant contribution to South African Actiniarian systematics to date, by recording an additional 23 species from the region (Carlgren 1938) in his 'Monograph of South African Actiniaria and Corallimorpharia' and raising the total number of South African actiniaria up to 41 species.

Following Carlgren's work, more than 40 years passed without any additional species being added to the anemone fauna, after which Dunn (1981) mentioned the presence of three tropical species, Entacmaea quadricolor, Heteractis magnifica and Stichodactyla mertensii in South Africa and England and Robson (1984) discovered Preactis millardae. This was followed by reports of two alien introductions in the region - Metridium senile from Cape Town Harbour, Table Bay (Griffiths et al. 1996) and Sagartia ornata from Saldanha Bay (Acuña et al. 2004). Subsequent to this, Schama et al. (2012) found that South African representatives of the species long known as 'Actinia equina' in fact represented an un-described, endemic species, which they named Actinia ebhayiensis. Finally, in the most recent addition to the fauna, Daly et al. (2012) described Edwardsia isimangaliso from Lake St Lucia.

Apart from these few taxonomic studies and a review of the species richness, endemicity and distribution patterns of the anemone fauna by Acuña and Griffiths (2004), no recent work has been undertaken on the South African sea anemones, resulting in an underestimation of both the richness of South African fauna and the distributional ranges of known species. In this study we contribute to the rectification of these shortcomings by collating an assortment of new data from museum collections, trawl surveys, SCUBA collected records, and our own field surveys to add both new anemone species to the South African fauna and to better document the true distributional ranges of existing species.

\section{Material and methods}

During three intensive sampling trips around South Africa, animals were gathered for examination from the east, south and west coasts. Areas mentioned in the text are displayed on a map in Figure 1.

Anemones were collected from the rocks using a specialised scraper tool, relaxed using $5 \mathrm{ml}$ of menthol crystals placed into sea water, and fixed in formalin. After 


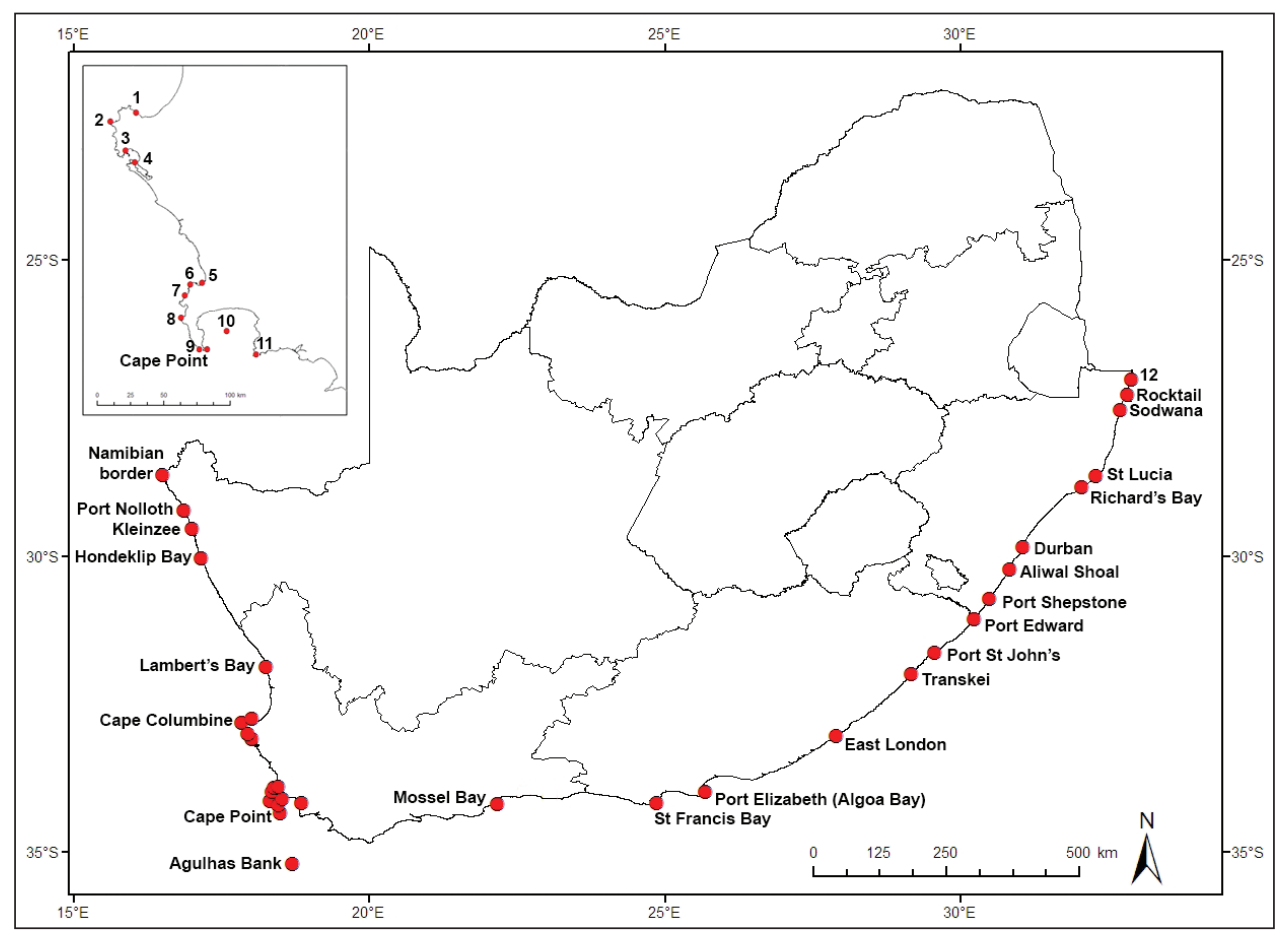

Figure I. Map of South Africa showing places mentioned in the text: I St Helena Bay 2 Cape Columbine 3 Saldanha Bay 4 Langebaan Lagoon 5 Table Bay 6 Sea Point 7 Oudekraal 8 Kommetjie 9 Cape of Good Hope 10 False Bay II Cape Hangklip, and 12 Bhanga Nek (Mozambique border).

three days, the formalin was replaced with $70 \%$ ethanol. Two collection methods were used during these surveys: collection off rocks exposed during spring low tide and collection from up to $30 \mathrm{~m}$ depth by SCUBA divers. As collection permits for Sodwana Bay and Rocktail Bay were not granted for this study, due to the value of these anemones to the SCUBA diving ecotourism industry, only photographic records were obtained in these areas. Following identification of wet material, all specimens were deposited in the Iziko South African Museum (SAM) marine invertebrate collection, along with digital copies of photographs and an Excel database containing details of all records. Synonymy lists were adapted from Hexacorallians of the World (Fautin 2013).

Additional datasets from previous rocky shore intertidal surveys around South Africa were generously provided by Dr Kerry Sink and Dr Angela Mead, and photographic records provided by recreational SCUBA divers were also included where the species could be identified with confidence. Additional specimens examined for this study included previously unexamined specimens from the Iziko South African Museum (SAM) collection, which included specimens collected by the University of Cape Town (UCT) Ecological Survey and specimens collected by the Department of Agriculture, Forestry and Fisheries (DAFF) during routine deep-sea trawl surveys. 
Attached to the locality data are depth records, enabling a depth range to be determined for each species. For the purposes of this study, the west coast was defined as stretching from the Namibian border to Cape Point, the south coast as stretching eastwards from Cape Point to the Mbashe River in the Transkei, and the east coast as stretching from the Mbashe River northwards to the Mozambique border.

\section{Results}

\section{History of discovery}

Figure 2 shows a timeline of the numbers of Actiniarian and Corallimorpharian species recorded from South Africa over the last two centuries. The enormous contributions made by Carlgren (1928a, 1938) are particularly striking, as is the very low level of taxonomic activity over the subsequent decades until present. Fourteen species new to South Africa were recorded during this study, including two new species currently undergoing description, making this the most significant contribution in terms of expansion of the fauna list since the monograph of Carlgren (1938). Following this study, the total number of Actiniaria and Corallimorpharia species recognised from South African waters is raised to 63 .

\section{New additions to the fauna}

The samples and data sources examined resulted in the addition of 14 anemone species to the South African fauna. These comprise two species new to science, both of which are currently being formally described elsewhere, plus 12 species new to the region.

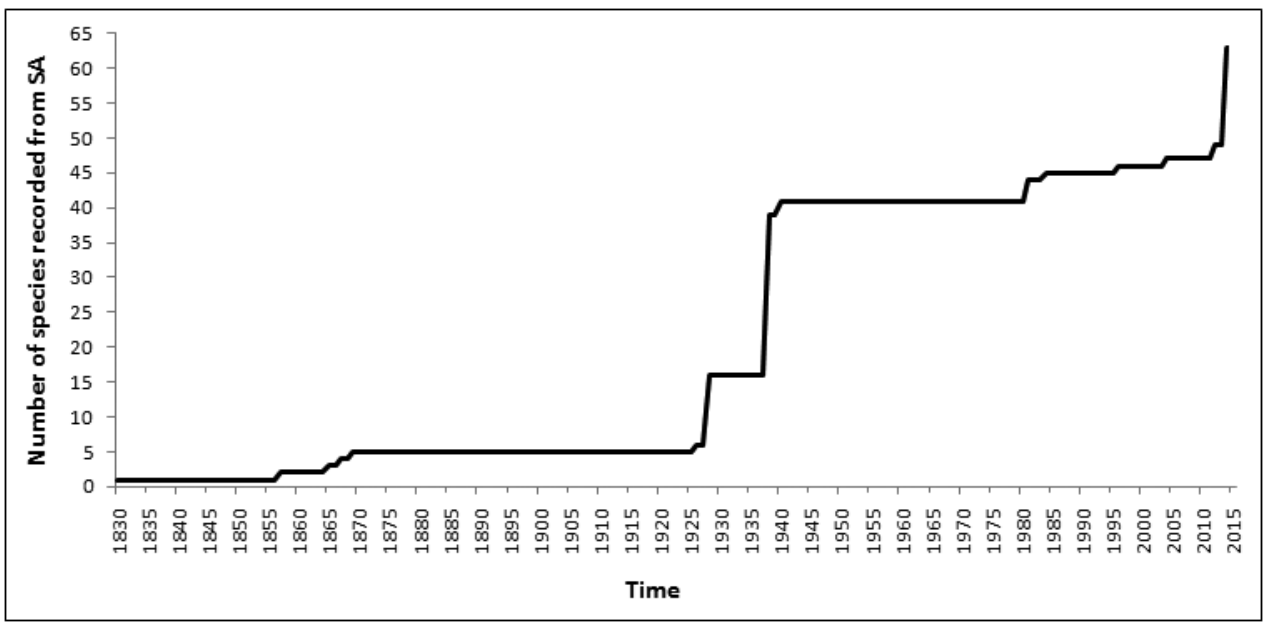

Figure 2. The number of species recorded from South Africa between 1830 and 2015. 
The following account summarises the previously known range of each of these species, details where South African specimens were found, mentions similar species known from South Africa, and lists museum specimens and selected photographs of each of the new species recorded.

Table 1 summarises the specimen and photographic data for each of the new records. Five of these new records are based on photographic evidence, while specimens exist for the remaining seven.

\section{Species new to science}

\section{Family Halcampidae Andres, 1883}

Genus Halianthella Kwietniewski, 1896

\section{Halianthella sp. $\mathbf{n}$.}

Fig. 3A

This very tiny species was discovered by Helen and Guido Zsilavecz while diving at $15 \mathrm{~m}$ in False Bay, near Cape Point. Specimens were sent to Dr Estefanía Rodríguez, assistant curator of the American Museum of Natural History, who is in the process of describing this material as a new species in the genus Halianthella. This species is thus referred to here as Halianthella sp. n., and it is known to SCUBA divers as the 'clown anemone'.
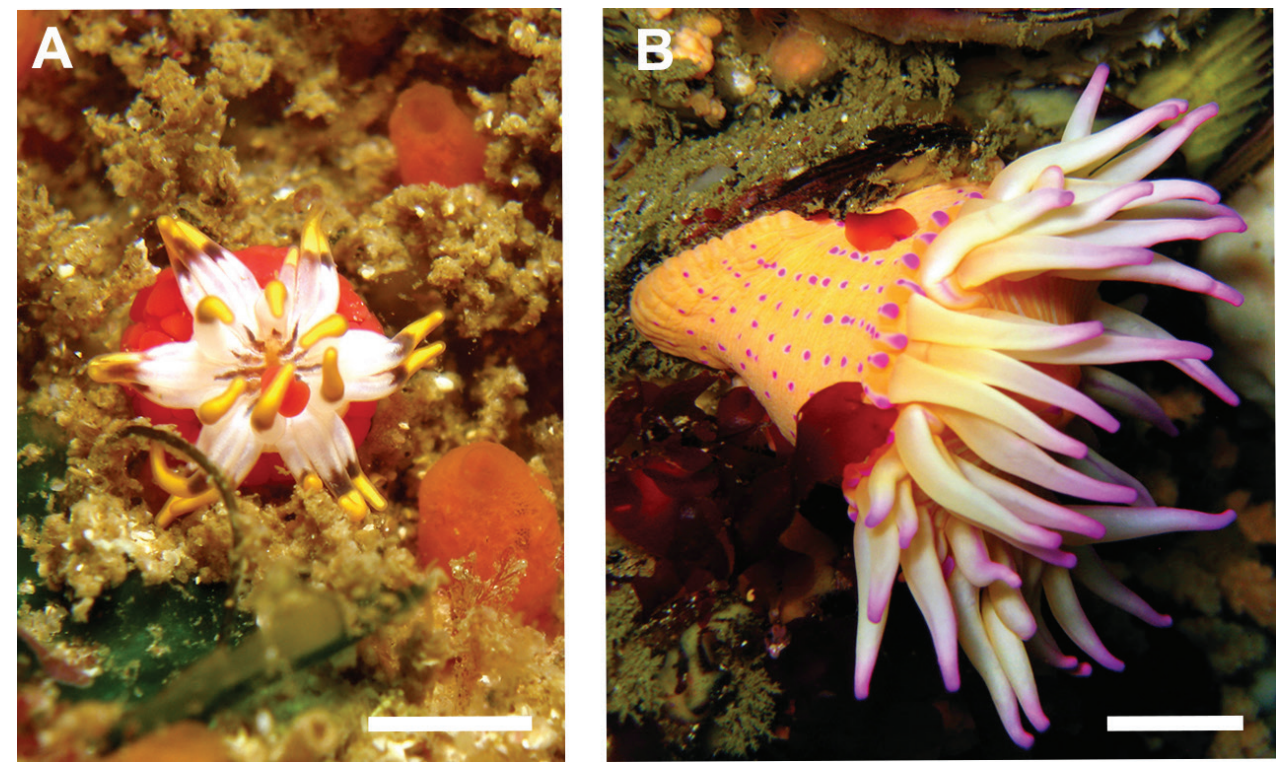

Figure 3. The two new species of sea anemone reported in this study: A Halianthella sp. n. $(3 \mathrm{~mm})$ and B Anthostella sp. n. (10 mm). Photographs taken by Guido Zsilavecz (A) and Megan Laird (B). 


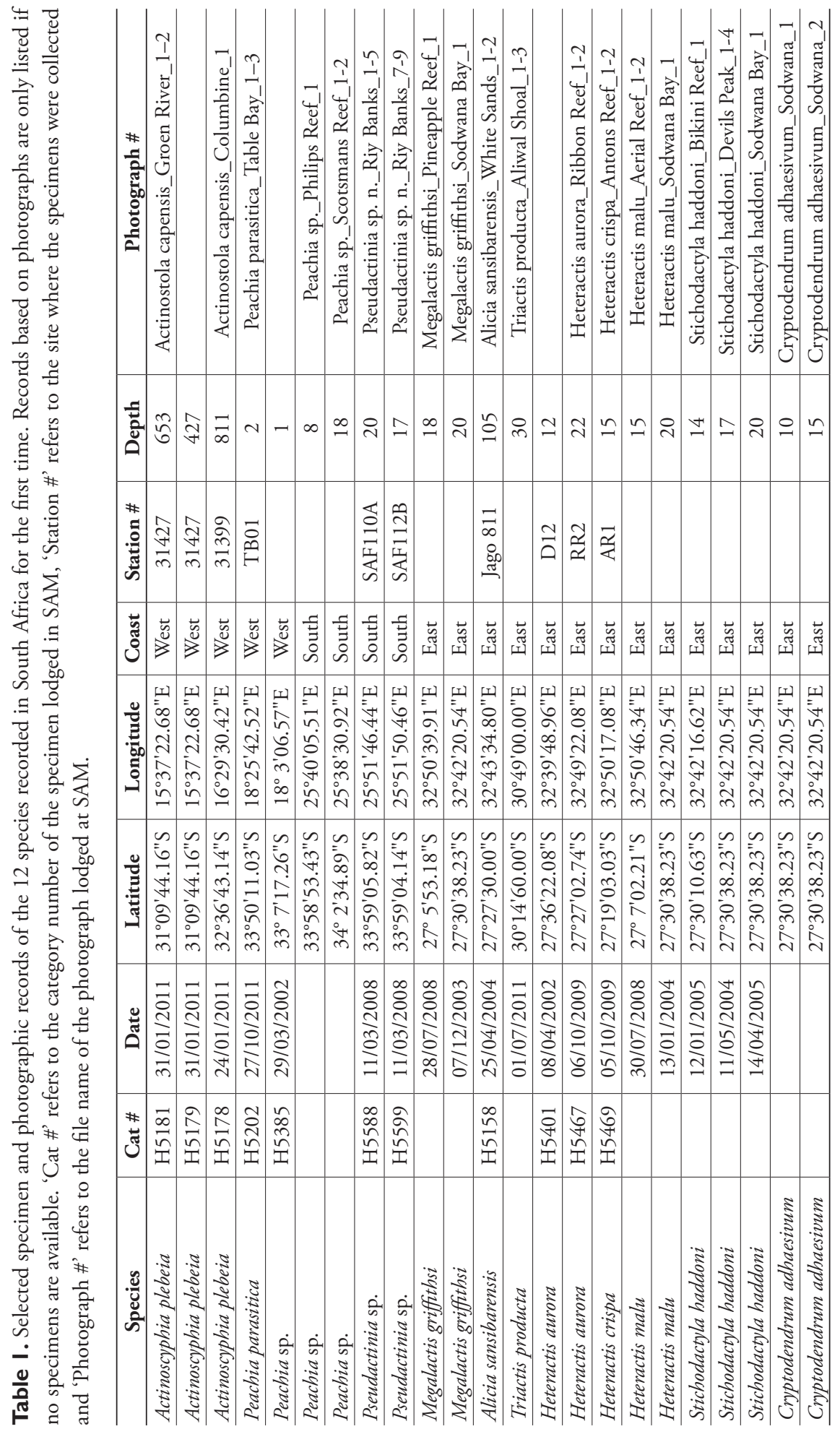




\section{Family Actiniidae Rafinesque, 1815 \\ Genus Anthostella Carlgren, 1938}

\section{Anthostella sp. n.}

Fig. 3B

The second new species, known to divers as the 'dwarf spotted anemone', was first collected by Prof. Charles Griffiths from Oudekraal. This species is referred to here as Anthostella sp. $\mathrm{n}$. as the formal publication of the description by Dr Estefanía Rodríguez and Dr Megan Laird is still pending.

\section{Species newly reported from South Africa}

\section{Family Actinoscyphiidae Stephenson, 1920 \\ Genus Actinoscyphia Stephenson, 1920 \\ Actinoscyphia plebeia (McMurrich, 1893)}

Fig. 4A

Actinernus plebeius McMurrich, 1893: 165-167, pl. 24, figs 42-45; Carlgren 1896: 174; Gravier 1918: 6-7; 1922: 31-32

Actinoscyphia plebeian: Fautin 1984: 37-40; Rodríguez 2012: 215

This species is previously known from Antarctica, Chile and the South Georgia Islands off Argentina. The addition of this species to the South African fauna is based on multiple trawl records from both the west and south coasts of South Africa collected by the Department of Agriculture, Forestry and Fisheries (DAFF) during annual trawl surveys. According to available records, it was first found in 2007 on the Agulhas Bank, but those specimens remained unidentified until this study. Three specimens are lodged in the Iziko South African Museum (SAM): H5181, H5179 and H5178 (Table 1) and additional records are based on trawl data with no supporting specimens. The distribution range of this species extends from Kleinzee on the west coast to the Agulhas Bank on the south coast, between $128-866 \mathrm{~m}$ depth. Actinoscyphia plebeia is distinguishable from Actinostola capensis, another deep-sea species found in the same area off the coast of South Africa, by the maroon coloration of its tentacles and oral disc, its smooth column and its slimy texture. 

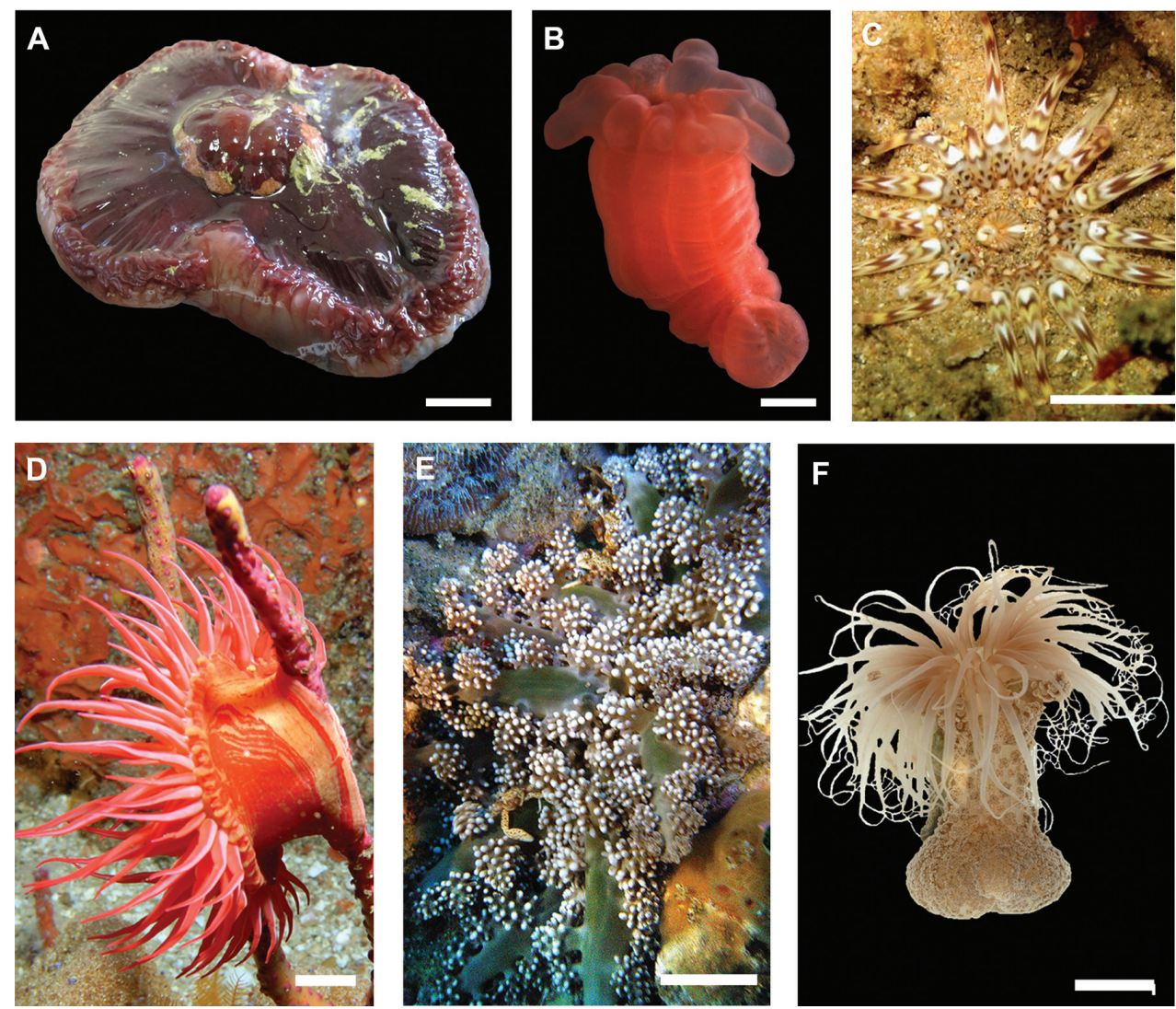

Figure 4. Six of the twelve species recorded from South Africa for the first time: A Actinoscyphia plebeia $(20 \mathrm{~mm})$ B Peachia paracitica $(2 \mathrm{~mm})$ C Peachia sp. $(20 \mathrm{~mm})$ D Pseudactinia sp. $(10 \mathrm{~mm})$ E Megalactis griffithsi $(10 \mathrm{~mm})$ and $\mathbf{F}$ Alicia sansibarensis $(20 \mathrm{~mm})$. Photographs taken by Dr Lara Atkinson (A), Dr Megan Laird (B, E), Andre Aggenbach (C), Dr Bernard Picton (D) and Dr Kerry Sink (F).

\section{Family Haloclavidae Verrill, 1899}

\section{Genus Peachia Gosse, 1855}

\section{Peachia parasitica (Agassiz, 1859)}

Fig. 4B

Bicidium parasiticum Agassiz, 1859: 23-24

Peachia parasitica: Verrill 1866: 338-339, 343; McDermott et al. 1982: 319-321

Previously known from east and west coasts of North America, as well as from the east coast of Greenland. The addition of this species to the South African fauna is based 
on a single specimen collected by Dr. Deborah Robertson-Andersson in 2011. The anemone was collected from Table Bay during a boat-based expedition targeting the collection of jellyfish. The juvenile was found attached to the underside of the medusa of the jellyfish Chrysaora fulgida. This specimen is lodged in SAM with catalogue number H5202 (Table 1). Peachia parasitica is distinguishable from Peachia sp. (below) by the unmarked tentacles and oral disc of the former, as well as the tendency of juveniles to live as parasites.

\section{Peachia sp.}

Fig. 4C

Due to a lack of well-preserved samples, it was not possible to determine the specific name of this anemone, thus the previous range is unknown. The addition of this species to the South African fauna is based on a single specimen found in $1 \mathrm{~m}$ of water and collected from Langebaan Lagoon in 2002. Two additional photographic records of this species exist, both from Port Elizabeth on the south coast, between 8-18 m depth. The specimen is lodged in SAM with catalogue number H5385 (Table 1). Peachia sp. is distinguishable from Peachia parasitica by the unmistakable chevron patterns on the tentacles.

\section{Family Actiniidae Rafinesque 1815 \\ Genus Pseudactinia Carlgren, 1928b}

\section{Pseudactinia sp.}

Fig. 4D

As it was not possible to determine the specific name of this anemone, the previous range is unknown. The addition of this species to the South African anemone fauna is based on two specimens collected from Algoa Bay in 2008, as well as 34 photographic records from the south coast. The distributional range of this species is recorded from False Bay to Aliwal Shoal from 1-29 m depth. The two specimens are lodged in SAM: H5588 and H5599 (Table 1) and additional records are based on photographic records collected by recreational SCUBA divers. Photographic records are not listed in Table 1 and are obtainable from SAM. Pseudactinia sp. is large and has a very wide oral disc, like that of $P$. flagellifera, but has only one row of vesicles, while $P$. flagellifera has up to five. Pseudactinia varia is much smaller than Pseudactinia sp., but also has one row of vesicles. Pseudactinia sp. is unique in that the column is often mottled and the oral disc is striped. The distinction between species is not purely morphological, but is also based on molecular studies (Heestand 2009). 


\section{Family Actinodendronidae Haddon, 1898 \\ Genus Megalactis Hemprich \& Ehrenberg, 1834 in Ehrenberg, 1834 \\ Megalactis griffithsi Saville-Kent, 1893}

Fig. 4E

Megalactis griffithsi Saville-Kent, 1893: 35, 147; Carlgren 1896: 175; 1949: 68; Haddon 1898: 399, 493-494; Stephenson 1922: 295; Uchida et al. 1975: 34-35; Fautin 1988: 25; Ardelean and Fautin 2004: 488, 491, 494, 500-501

This species is previously known from the area around Melanesia, Polynesia and Micronesia. The addition of this species to the South African fauna is based on two photographic records, one from Sodwana Bay and the other from Rocktail Bay. Megalactis griffithsi was first recorded in 2003 (Table 1) and is know from depths of 18-20 m. The original photograph remained unidentified until this species was again encountered during a research dive that formed part of this study in 2008 . Although the specimen was not collected, it was possible to observe the behaviour of the anemone, and based on this, as well as the external morphology visible in photographs, the species name was determined. Megalactis griffithsi is distinguishable from Actinodendron hansingorum and other species of the genus by the alternating dark and light areas between each segment of the oral disc. The number of secondary branches on the tentacles also does not exceed 35 in number (Ardelean and Fautin 2004).

\section{Family Aliciidae Duerden, 1895 \\ Genus Alicia Johnson, 1861}

\section{Alicia sansibarensis Carlgren, 1900}

Fig. 4F

Alicia sansibarensis Carlgren, 1900: 28-30; Parulekar 1990: 219-220, 223, 225; Pax 1909: 402; Stephenson 1922: 280; Carlgren 1927b: 444; 1949: 43

This species was previously considered endemic to Zanzibar. The addition of this species to the South African fauna is based on one specimen from Sodwana Bay collected from $105 \mathrm{~m}$ depth in 2004. This specimen remained unidentified until now due to a lack of taxonomic expertise. The anemone is lodged in SAM with catalogue number H5158 (Table 1). Alicia sansibarensis is distinguishable from Triactis producta, the only other species of the family Aliciidae found in South Africa, by the division of the column of $A$. sansibarensis into a scapus and a capitulum. The tentacles of $A$. sansibarensis are very long and snake-like, while those of $T$. producta are short. 


\section{Genus Triactis Klunzinger, 1877}

\section{Triactis producta Klunzinger, 1877}

Fig. 5A

Triactis producta Klunzinger, 1877: 85-86, pl. 6, fig. 8; Carlgren 1947: 14; 1949: 44. Fishelson 1970: 107-108, fig. 5; Fautin et al. 2008: 39-40, 51-52 Hoplophoria cincta Haddon, 1898: 398, 438-439; pl. 23, figs 11-15; Carlgren 1947: 14 Triactis cincta: Carlgren 1945: 7; 1949: 44; 1950: 427, 433

This species is previously known from across most of the Indo-Pacific. The addition of this species to the South African fauna is based on one photographic record from a 30 $\mathrm{m}$ dive at Aliwal Shoal in 2011 (Table 1). It was possible to determine the species of the anemone conclusively based on external morphology visible in photographs. This anemone is unique in that it possesses pseudotentacles that function to maximise photosynthesis by zooxanthellae. Triactis producta is distinguishable from Alicia sansibarensis by the presence of bifurcated stalked outgrowths protruding from mid-column.

\section{Family Stichodactylidae Andres, 1883 \\ Genus Heteractis Milne Edwards \& Haime, 1851}

\section{Heteractis aurora (Quoy \& Gaimard, 1833)}

Fig. 5B

Actinia aurora Quoy \& Gaimard, 1833: 141-142, pl. 12, fig. 1-4

Heteractis aurora: Milne Edwards 1857: 261; Carlgren 1949: 108; Dunn 1981: 3940, 56-66, 105, 107-108; Hirose 1985: 114, 116-121, 123-125; Cutress and Arneson 1987: 54, 55, 57, 59, pl. 2, fig. 2f; England 1988: 45-54; Badsha 1991: 139-144; den Hartog 1994: 75, 77-78

Antheopsis koseirensis England, 1987: 207, 273, 276

Bunodes koseirensis: England 1988: 53

This species is previously known from across most of the Indo-Pacific. The addition of this species to the South African fauna is based two specimens from Sodwana Bay. The first specimen was found in 2002, but remained unidentified until the collection of the second specimen in 2009. Subsequently, numerous sightings have been reported between depths of 12-15 m, with one sighting at Aliwal Shoal. The two specimens are lodged in SAM: H5401 and H5467 as shown in Table 1; with six additional photographic records not listed here, but obtainable from the SAM database. Heteractis aurora is distinguishable from other species of the genus by the 'beaded' tentacles formed by swellings along their length. 

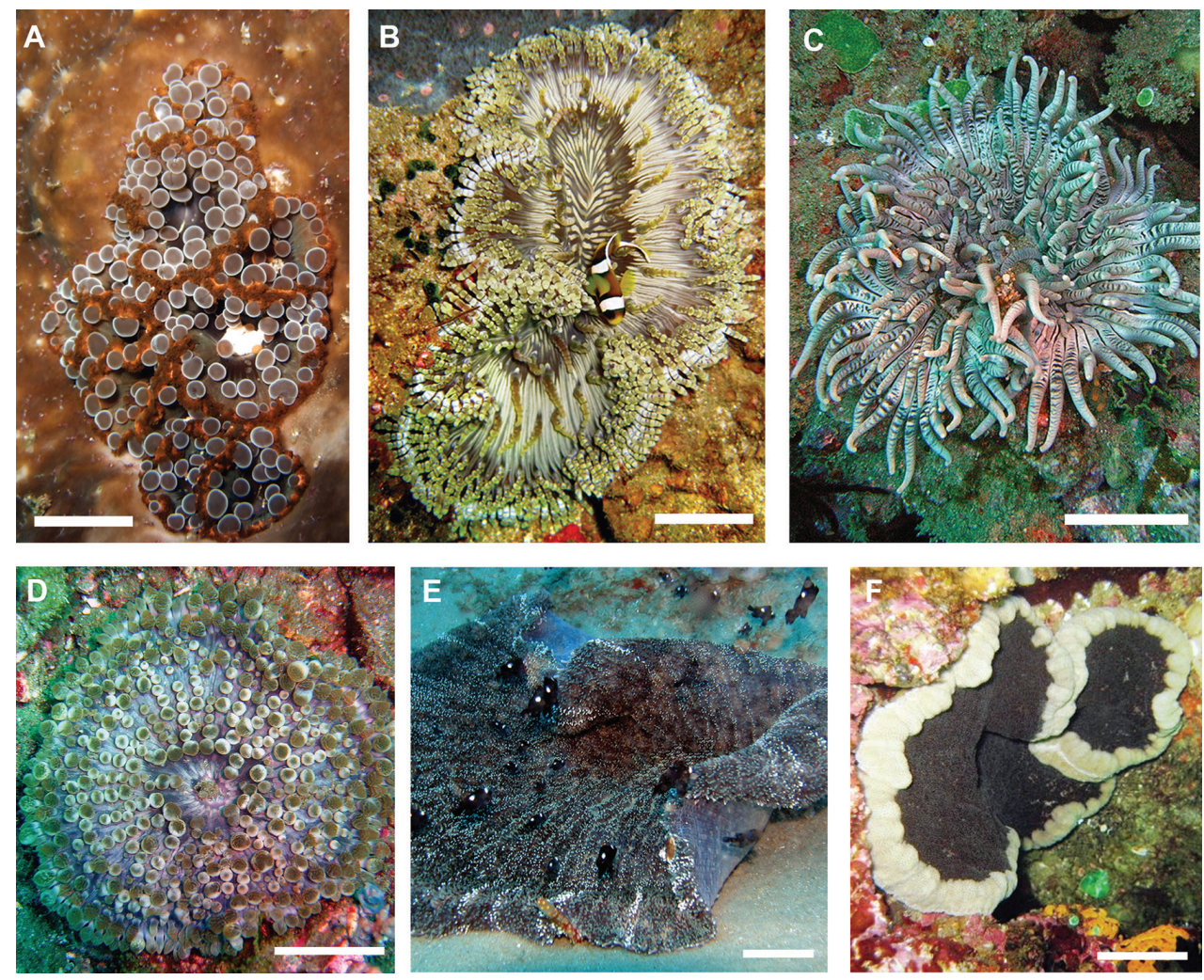

Figure 5. Six of the twelve species recorded from South Africa for the first time: A Triactis producta $(30 \mathrm{~mm})$ B Heteractis aurora $(50 \mathrm{~mm})$ C Heteractis crispa $(50 \mathrm{~mm})$ D Heteractis malu $(40 \mathrm{~mm})$ E Stichodactyla haddoni $(100 \mathrm{~mm})$ and $\mathbf{F}$ Cryptodendrum adhaesivum $(150 \mathrm{~mm})$. Photographs taken by Dr Megan Laird (A-C, F), Christo Van Jaarsveld (D) and Dr Kerry Sink (E).

\section{Heteractis crispa (Hemprich \& Ehrenberg in Ehrenberg, 1834)}

Fig. 5C

Actinia Entacmaea crispa Ehrenberg, 1834: 260, pl. 8, fig. 1

Entacmaea crispa Carlgren, 1899: 14

Heteractis crispa Dunn, 1981: 47-57, 65, 71. Hirose 1985: 114, 116-125. Fautin

1986: 172-173, 179. Richardson et al. 1997: 60-65. Hattori 2006: 51-56. Scott and Harrison 2007a: 163-169; 2007b: 110-119; 2008: 833-838. Fautin et al. 2009: 121, 123, 134-135, 136, 139, 140

Heteractis macrodactylum Cutress \& Arneson, 1987: 54-55, 57, 59, pl. 2, fig. 2d Radianthus crispus Uchida \& Soyama, 2001: 91, 151, 155

The range of this species extends across most of the Indo-Pacific. The addition of Heteractis crispa to the South African fauna is based on one specimen from Sodwana Bay found during a field survey for this study in 2009. This specimen is lodged in 
SAM with catalogue number H5469 (Table 1). The seven photographic records are obtainable from the SAM database. The distributional range of this species in South Africa is from Aliwal Shoal to Rocktail Bay, between 15-22 m depth. Heteractis crispa is distinguishable from other species of the genus by the frosted stripes on each tentacle and the thick, leathery column.

\section{Heteractis malu (Haddon \& Shackleton, 1893)}

Fig. 5D

Discosoma Malu Haddon \& Shackleton, 1893: 117, 120

Heteractis malu Dunn, 1981: 35, 40, 47, 57, 66-71, 104, 107-108

Radianthus malu England, 1988: 53

This species is previously known from across most of the Indo-Pacific. The addition of Heteractis malu to the South African fauna is based on two photographic records from Sodwana Bay from 15-20 m, with the first taken by a SCUBA diver in 2004 (Table 1). The species was encountered again during a field survey for this study in 2008 . Although the anemone was not collected, it was possible to conclusively determine the species based on external morphology visible in photographs. They show adhesive verrucae on the column, as well as short, sparse tentacles (Fautin et al. 2008).

\section{Genus Stichodactyla Brandt, 1835}

\section{Stichodactyla haddoni (Saville-Kent, 1893)}

Fig. 5E

Discosoma Haddoni Saville-Kent, 1893: 32-33. Carlgren 1896: 174

Stichodactyla haddoni Dunn, 1981: 82-91. Fautin and Allen 1992: 40-41. Fautin et al. 2009: 133

The range of this species extends across most of the Indo-Pacific. The addition of Stichodactyla haddoni to the South African fauna is based on three photographic records from Sodwana Bay in 14-20 m of water. The anemone was first recorded by a SCUBA diver in 2004, with two additional photographs taken in 2005 (Table 1). No South African specimens of this anemone are housed in SAM; however, a specimen from just north of the Mozambique border is in the museum collection. As this is a large anemone, it was possible to determine the species based on external morphology visible in photographs. Stichodactyla haddoni is usually easily distinguishable from $S$. mertensii, as $S$. haddoni is usually found in sand, has a weakly adherent pedal disc, has extremely sticky tentacles, has a column that is unable to contract completely, and has a maximum oral disc diameter of $500 \mathrm{~mm}$. In contrast, $S$. mertensii is found attached 
to coral reef, has an extremely adhesive pedal disc, has non-adherent tentacles, is able to slowly contract into crevices (Fautin and Allen 1997) and has a maximum oral disc diameter of $1500 \mathrm{~mm}$.

\section{Family Thalassianthidae Milne Edwards, 1857 \\ Genus Cryptodendrum Klunzinger, 1877}

\section{Cryptodendrum adhaesivum Klunzinger, 1877}

Figure $5 \mathrm{~F}$

Cryptodendrum adhäsivum Klunzinger, 1877: 86

Cryptodendrum adhaesivum Haddon, 1898: 399, 483-484, pl. 25, figs 4-6, pl. 32, figs 5-6. Carlgren 1940b: 7, 32-34, figs 9,13; 1949: 70. Dunn 1981: 7-13. Cutress and Arneson 1987: 54, 55, 57, 59, pl. 2, fig. 2c. Richardson et al. 1997: 61-62, 64. Fautin 2009: 131-132, 140, fig. 11

This species is previously known from across most of the Indo-Pacific. The addition of this species to the South African fauna is based on two photographic records taken between 10-15 $\mathrm{m}$ at Sodwana Bay during SCUBA diving surveys for this study (Table 1). As this is a large anemone, it was possible to determine the species based on external morphology visible in photographs. C. adhaesivum is unlike other South African anemones, as it has two forms of tentacles: inner tentacles each with five branches at tip, and outer tentacles with a single bulb at tip (Fautin and Allen 1997).

\section{Range expansion}

Since the work of Carlgren (1938) and the distributional review by Acuña and Griffiths (2004), a large amount of distributional data for anemones has been collected. These data have been stored in museums and on online databases such as 'Hexacorallians of the world' (Fautin 2013), but these ranges have never before been collated and published.

The range expansion of Metridium senile is the most notable, as this is one of two alien anemone species known in South Africa. This species was first recorded in South Africa from the Table Bay Harbour (Griffiths et al. 1996) in September 1995, when a well-established colony was discovered. Anemones were attached to artificial substrata, such as car tyres, at a depth of 10-16 m, and it is thought that the species was introduced to South Africa via shipping from Europe (Griffiths et al. 1996). However, in February 2006, another population of M. senile was discovered at $115 \mathrm{~m}$ on the

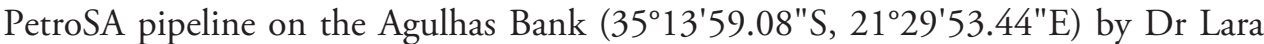
Atkinson. Individuals were morphologically identical to those of the Table Bay population and it was interesting to note that both populations were established on artificial 
structures. The size of each of these alien populations should be monitored annually to ensure that their range does not expand.

Other species for which range expansions have been detected since the work of Carlgren (1938) and Acuña and Griffiths (2004) are listed in Table 2. The distribution ranges of eight species were extended to the west, 18 species to the east, and 13 species to both the west and the east (Table 2). The fact that the ranges of so many species have been expanded, suggests that sea anemones around the South African coastline have been severely under-sampled in the past.

\section{Discussion and conclusions}

Since the writings of Carlgren (1927a, 1928a, 1938, 1940a, 1949), very little South African work has been done on the taxonomy of this group. The most recent species list available is that compiled by Acuña and Griffiths (2004), who reported 49 species of sea anemones from South Africa. Following extensive fieldwork and examination of unidentified anemones in the Iziko South African Museum (SAM) during the course of this study, the number of sea anemone species know from South Africa is hereby increased to 63. This number is high in comparison to the 30 species reported from the Faroe Islands (Fautin et al. 2005) and the 26 species from Galicia in north-western Spain (den Hartog and Ates 2011), but is on a par with the 63 species recorded from Chile (Häussermann 2006). The South African sea anemone fauna makes up over 5\% of the total anemone species worldwide when compared to the species list published by Daly et al. (2007). An increase of 14 species in one country over a relatively short study suggests that many more anemone species are still to be found in South Africa. The ranges of $79 \%$ of the anemone species reported by Acuna and Griffiths (2004) were also expanded by this study. Gaps in sample coverage remain particularly obvious in deep-sea areas, particularly the bathyal (500-3500 m) and the abyssal (3500-5000 m), the latter being essentially completely unexplored. Geographically, the west and east coasts need to be more thoroughly sampled, while estuarine habitats also need to be made a priority.

Eight of the 14 species added to the fauna were found on the east coast, with seven discovered by SCUBA divers and one collected in a trawl. Two of the new additions were found on the west coast, one a shallow water species found burrowing in sand and the other a pelagic species found on the medusa of a jellyfish. Two of the new records were found on the south coast by SCUBA divers, and a further two species were found to inhabit areas extending from the west to the south coast, with one found by SCUBA divers and the other retrieved by a deep-sea trawl. All of the east coast records are tropical forms previously well known from the Indo-Pacific. The use of SCUBA divers as a collection method for sea anemones has resulted in the addition of 10 of the 14 new records. This method was not available to Carlgren, which probably explains why these species were missed by him. As they occur at depths of $2 \mathrm{~m}$ and deeper, they are beyond the reach of rocky shore researchers, while at the same time being too shallow, or occurring in reef 


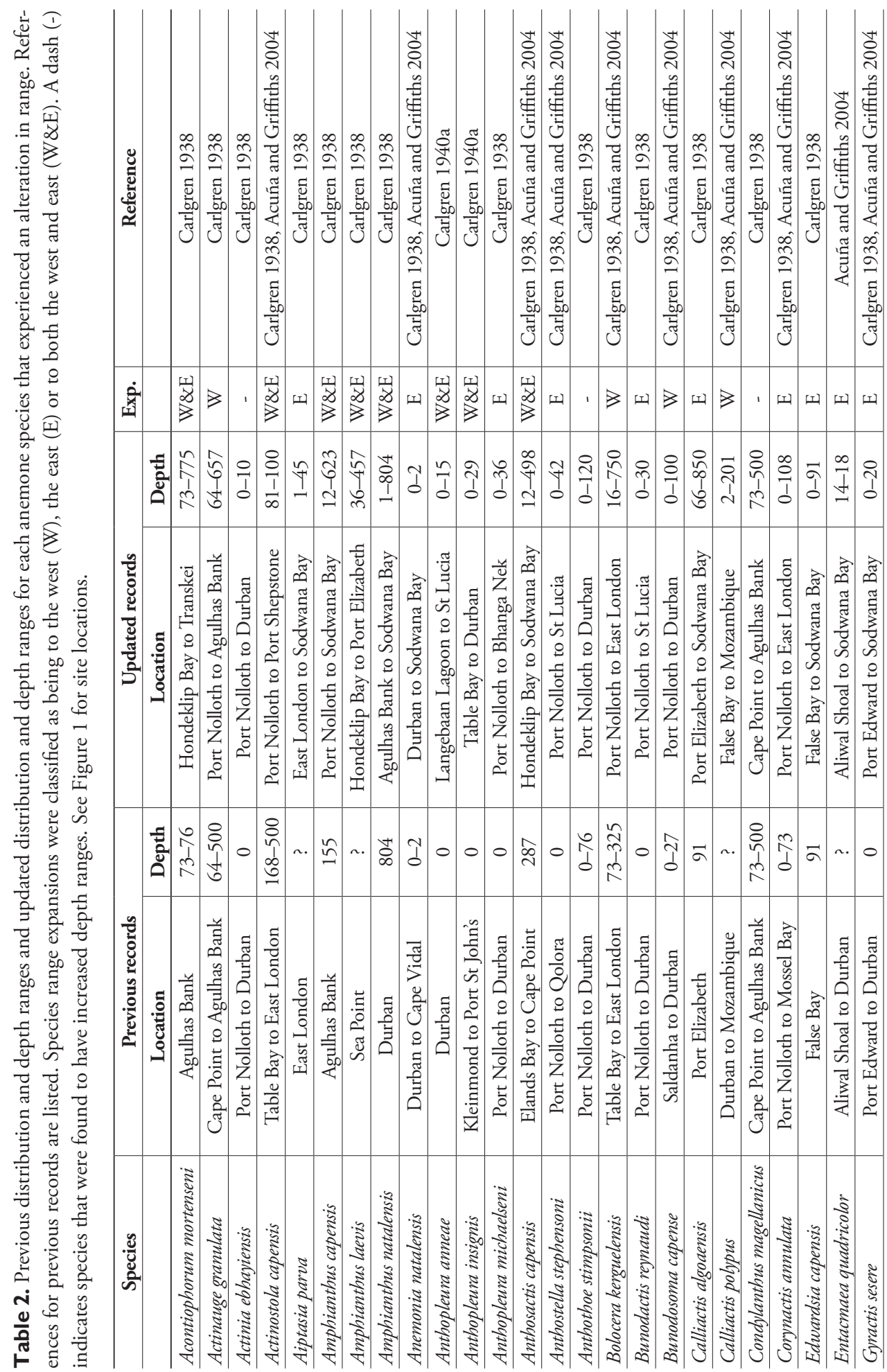




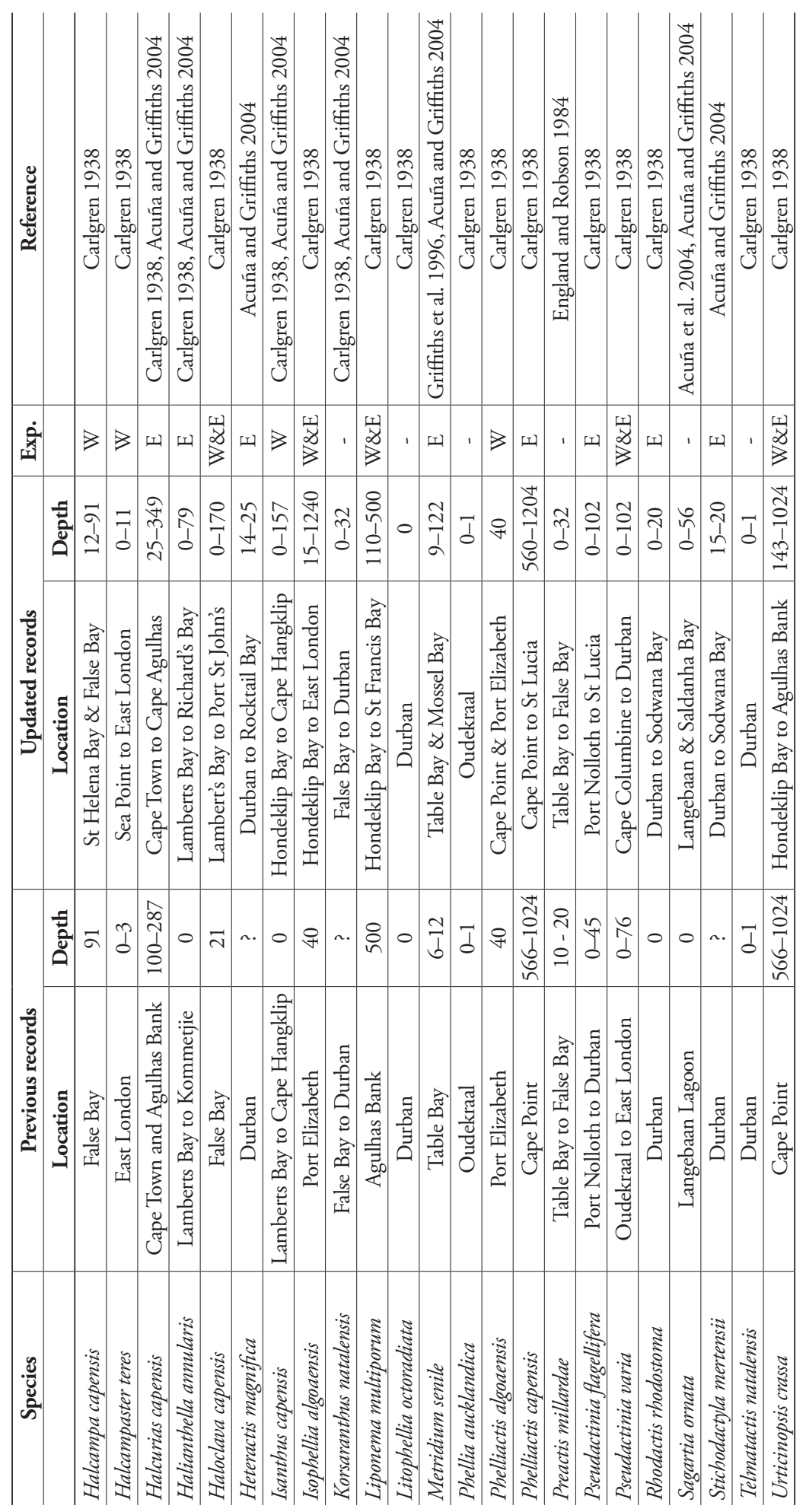


habitats that could not be sampled using ship-borne equipment such as grabs, dredges and trawl nets. This emphasises the importance of recreational SCUBA divers in the discovery of new species within this and other groups that are abundant on shallow rocky reefs.

\section{Acknowledgements}

Thanks to the Department of Agriculture, Forestry and Fisheries (DAFF) for access to their invaluable trawl dataset and the Iziko South African Museum for access to historical records. Access was granted by the iSimangaliso Wetland Park, SANParks and Cape Nature to conduct fieldwork in their respective reserves. Specimen collection was carried out with a research collecting permit issued to Prof. Charles Griffiths jointly by DAFF and the Department of Environmental Affairs (DEA). This research was funded by a National Research Foundation (NRF) grant to Prof. Charles Griffiths, a South African National Biodiversity Institute (SANBI) scholarship awarded to Megan Laird, as well as a number of University of Cape Town bursaries.

\section{References}

Acuña FH, Excoffon AC, Griffiths CL (2004) First record and redescription of the introduced sea anemone Sagartia ornata (Holdsworth, 1855) (Cnidaria: Actiniaria: Sagartiidae) from South Africa. African Zoology 39: 314-318.

Acuña FH, Griffiths CL (2004) Species richness, endemicity and distribution patterns of South African sea anemones (Cnidaria: Actiniaria \& Corallimorpharia). African Zoology 39: 193-200.

Agassiz L (1859) On some new actinoid polyps of the coast of the United States. Proceedings of the Boston Society of Natural History 7: 23-24.

Andres A (1883) Le Attinie (Monografia). Roma, 460 pp.

Ardelean A, Fautin D (2004) A new species of the sea anemone Megalactis (Cnidaria: Anthozoa: Actiniaria: Actinodendridae) from Taiwan and designation of a neotype for the type species of the genus. Proceedings of the Biological Society of Washington 117: 488-504.

Badsha AA (1991) Taxonomy of Sea Anemones of Tamilnadu Coast with a Note on Assessing the Suitability of Using a Few Species as Biological Indicators of Pollution. Department of Zoology, Presidency College, Madras, 144 pp.

Brandt JF (1835) Polypos, Acalephas Discophoras et Siphonophoras, nec non Echinodermata Continens. Sumptibus Academiae. Petropoli, 76 pp.

Carlgren O (1896) Annual report on the anthozoans for 1892 and (1893). Archiv für Naturgeschichte [Archives of Natural History] 62: 145-180. [In German]

Carlgren O (1899) Actiniaria and Zoantharia. Symbolae Physicae Supplement, 13-16. [In German] Carlgren O (1900) East African Actinia. Collected by Dr. F. Stuhlmann 1888 and (1889). Mittheilungen aus dem Naturhistorischen Museum [Communications from the Natural History Museum] 17: 21-144. [In German] 
Carlgren O (1927a) Actiniaria and Zoantharia. In: Odhner T (Ed.) Further Zoological Results of the Swedish Antarctic Expedition 1901-1903. Norstedt \& Söner, Stockholm, 1-102.

Carlgren O (1927b) Report on the Actiniaria and Ceriantharia. Transactions of the Zoological Society of London 22: 443-445.

Carlgren O (1928a) Actiniaria from the German Deep-sea Expedition. Scientific Results of the German Deep-sea Expedition on the Steamship "Valdivia" from 1898-1899 22: 125-266. [In German]

Carlgren O (1928b) Symbiosis between Actiniaria and Paguriden. Zeitschrift für Morphologie und Ökologie der Tiere [Journal of Morphology and Ecology of Animals] 12: 165-173. [In German]

Carlgren O (1938) South African Actiniaria and Zoantharia. Kungliga Svenska Vetenskapsakademiens Handlingar [The Royal Swedish Academy of Science Documents] 17: 1-148. [In Swedish]

Carlgren O (1940a) Some new South African Actiniaria and Zoantharia. Arkiv für Zoologi [Arcive for Zoology] 32: 1-7.

Carlgren O (1940b) Eastern Pacific Expeditions of the New York Zoological Society. XIX. Actiniaria from the Gulf of California. Zoologica 25: 211-219.

Carlgren O (1945) Further contributions to the knowledge of the cnidom in the Anthozoa especially in the Actiniaria. Kungliga Fysiografiska Sällskapets Handlingar [Royal Physiographic Society Documents] 56: 1-24.

Carlgren O (1947) Further contributions to a revision of the Actiniaria and Corallimorpharia. Arkiv für Zoologi [Arcive for Zoology] 17: 1-17.

Carlgren O (1949) A survey of the Ptychodactiaria, Corallimorpharia and Actiniaria. Kungliga Svenska Vetenskapsakademiens Handlingar [The Royal Swedish Academy of Science Documents] 1: 1-121.

Carlgren O (1950) Actiniaria and Zoantharia from South Australia. Arkiv für Zoologi [Arcive for Zoology] 20: 121-135.

Cutress CE, Arneson CA (1987) Sea anemones of Enewetak Atoll. In: Devaney DM, Reese ES, Burch EL, Helfrich P (Eds) The Natural History of Enewetak Atoll. Office of Scientific and Technical Information, US Department of Energy, 53-62.

Daly M, Brugler MR, Cartwright P, Collins AG, Dawson MN, Fautin D, France SC, McFadden CS, Opresko DM, Rodríguez E, Romano SL, Stake JL (2007) The phylum Cnidaria: A review of phylogenetic patterns and diversity 300 years after Linnaeus. Zootaxa 1668: 127-182.

Daly M, Perissinotto R, Laird M, Dyer D, Todaro A (2012) Description and ecology of a new species of Edwardsia de Quatrefages, 1842 (Anthozoa, Actiniaria) from the St Lucia Estuary, South Africa. Marine Biology Research 8: 233-245. doi: 10.1080/17451000.2011.617757

Den Hartog JC (1994) Sea anemones of the Seychelles. In: Van Der Land J (Ed.) Oceanic Reefs of the Seychelles. National Museum of Natural History, Leiden, 75-79.

Duerden JE (1895) On the genus Alicia (Cladactis), with an anatomical description of $A$. costae, Panc. Annals and Magazine of Natural History 15: 213-218. doi: $10.1080 / 00222939508677871$

Dunn DF (1981) The clownfish sea anemones: Stichodactylidae (Coelenterata: Actiniaria) and other sea anemones symbiotic with Pomacentrid fishes. Transactions of the American Philosophical Society 71: 3-115. doi: 10.2307/1006382 
Ehrenberg CG (1834) Contributions to the knowledge of the Corallenthiere in the Red Sea. Abhandlungen der Königlichen Akademie der Wissenschaften zu Berlin [Memoirs of the Royal Academy of Sciences in Berlin] 1: 1-156. [In German]

England KW (1987) Certain Actiniaria (Cnidaria, Anthozoa) from the Red Sea and tropical Indo-Pacific Ocean. Bulletin of the British Museum (Natural History) 53: 205-292.

England KW (1988) Redefinitions and systematics of Heteractis aurora, the genera Heteractis and Radianthus, and the family Heteractidae (Cnidaria: Actiniaria). Indo-Malayan Zoology 5: 45-55.

England KW, Robson EA (1984) A new sea anemone from South Africa (Anthozoa, Ptychodactiaria). Annals of the South African Museum 94: 305-329.

Fautin D (1984) More Antarctic and Subantarctic sea anemones: (Coelenterata, Corallimorpharia and Actiniaria). In: Kornicker LS (Ed.) Biology of the Antarctic Seas XVI, Antarctic Research Series, Volume 41. American Geophysical Union, 1-42. doi: 10.1029/AR041p0001

Fautin D (1986) Why do anemonefishes inhabit only some host actinians? Environmental Biology of Fishes 15: 171-180. doi: 10.1007/BF00002992

Fautin D (1988) Sea anemones (Actiniaria and Corallimorpharia) of Madang Province. Science in New Guinea 14: 22-29.

Fautin D (2009) Structural diversity, systematics, and evolution of cnidae. Toxicon 54: 1054-1064. doi: 10.1016/j.toxicon.2009.02.024

Fautin D (2013) Hexacorallians of the World. http://hercules.kgs.ku.edu/hexacoral/anemone2/index.cfm [accessed 19 June 2014]

Fautin D, Allen G (1992) Field Guide To Anemone Fishes And Their Host Sea Anemones. Western Australian Museum, Pearth, Western Australia, 160 pp.

Fautin DG, Allen GR (1997) Anemone Fishes and Their Host Sea Anemones: A Guide for Aquarists and Divers. (Revised edition). Sea Challengers Perth, Western Australia, 160 pp.

Fautin D, Crowther AL, Wallace CC (2008) Sea anemones (Cnidaria: Anthozoa: Actiniaria) of Moreton Bay. In: Davie PJF, Phillips JA (Eds) Proceedings of the $13^{\text {th }}$ International Marine Biological Workshop, The Marine Fauna and Flora of Moreton Bay, Queensland. Memoirs of the Queensland Museum, 35-64.

Fautin D, Daly M, Cappola V (2005) Sea anemones (Cnidaria: Actiniaria) of the Faroe Islands: A preliminary list and biogeographic context. Annales Societatis Scientiarum Færoensis Supplementum [Annual Supplement of the Society] 41: 77-87.

Fautin D, Tan SH, Tan R (2009) Sea anemones (Cnidaria: Actiniaria) of Singapore: abundant and well-known shallow-water species. Raffles Bulletin of Zoology 22: 121-143.

Fishelson L (1970) Littoral fauna of the Red Sea: the population of non-scleraetinian anthozoans of shallow waters of the Red Sea (Eilat). Marine Biology 6: 106-116. doi: 10.1007/ BF00347239

Gosse PH (1855) Description of Peachia hastata, a new genus and species of the Class Zoophyta; with observations on the Family Actiniadæ. Transactions of the Linnean Society of London 21: 267-276. doi: 10.1111/j.1096-3642.1852.tb00463.x

Gravier C (1918) Preliminary note on the hexactiniaires collected during cruises of Princess Alice and the Hirondelle from 1888 to 1913 inclusive. Bulletin de l'Institut Océanographique (Monaco) [Bulletin of the Oceanographic Institute] 346: 1-24. [In French] doi: 10.5962/bhl.part.8664 
Griffiths CL, Kruger LM, Smith CE (1996) First record of the sea anemone Metridium senile from South Africa. South African Journal of Zoology 31: 157-158. doi: 10.1080/02541858.1996.11448407

Haddon AC (1898) The Actiniaria of Torres Straits. Scientific Transactions of the Royal Dublin Society 6: 393-520.

Haddon AC, Shackleton AM (1893) Description of some new species of Actiniaria from Torres Straits. Scientific Proceedings of the Royal Dublin Society 8: 116-131.

den Hartog J, Ates RML (2011) Actiniaria from Ria de Arosa, Galicia, northwestern Spain, in the Netherlands Centre for Biodiversity Naturalis, Leiden. Zoologische Mededelingen 85: 11-53.

Hattori A (2006) Vertical and horizontal distribution patterns of the giant sea anemone Heteractis crispa with symbiotic anemonefish on a fringing coral reef. Journal of Ethology 24: 51-57. doi: 10.1007/s10164-005-0160-8

Häussermann V (2006) Biodiversity of Chilean sea anemones (Cnidaria: Anthozoa): distribution patterns and zoogeographic implications, including new records for the fjord region. Investigaciones marinas 34(2): 23-35. doi: 10.4067/s071771782006000200003

Heestand EN (2009) Phylogeny and Evolution of Anthopleura (Cnidaria: Anthozoa: Actiniaria). Unpublished MSc thesis, Ohio State University, Columbus.

Hirose Y (1985) Habitat, distribution and abundance of coral reef sea-anemones (Actiniidae and Stichodactylidae) in Sesoko Island, Okinawa, with notes on expansion and contraction behavior. Galaxea 4: 113-127.

Johnson JY (1861) Notes on the sea-anemones of Madeira, with descriptions of new species. Proceedings of the Zoological Society of London 1861: 298-306.

Klunzinger CB (1877) The Korallthiere of the Red Sea 1: The Alcyonarien and Malacodermen. Gutmann'schen Buchhandlung, Berlin, 98 pp. [In German]

Kwietniewski CR (1896) Revision of the Actinia collected by Prof. Studer on the journey of the Gazelle Corvette. Jenaische Zeitschrift für Naturwissenschaft [Jenaische Journal of Natural Science] 30: 583-603. [In German]

Lesson RP (1830) Description of animals of the family Actiniaria found during the travels of the King's College in the her Majesties' Corvetteette La Coquille during the years 1822, 1823,1824 , and 1825, under the Ministry and in accordance with instructions of S. E. M. de Marquis de Clermont-Tonnerre. Arthus Bertrand, Paris, 67-83. [In French]

McDermott JJ, Zubkoff PL, Lin AL (1982) The occurrence of the anemone Peachia parasitica as a symbiont in the Scyphozoan Cyanea capillata in the Lower Chesapeake Bay. Coastal and Estuarine Research Federation 5: 319-321. doi: 10.2307/1351756

McMurrich J (1893) Report on the Actiniaria collected by the United States Fish Commission Steamer Albatross during the winter of 1887-1888. Proceedings of the United States National Museum 16: 119-216. doi: 10.5479/si.00963801.16-930.119

Milne Edwards H (1857) Natural history of polyps volume 1. Librairie Encyclopédique de Roret, Paris, 326 pp. [In French]

Milne Edwards H, Haime J (1851) Archives of the Museum of Natural History. Gide et J. Baudry, Paris, 502 pp. [In French] 
Parulekar A (1990) Actinarian sea anemone fauna of India. Proceedings of Marine Biodeterioration with Reference to Power Plant Cooling Systems IGCAR, Kalpakkam, 26-28 April 1989, National Institute of Oceanography, 218-228.

Pax F (1909) The Actinia of the East African Islands. In: Voeltzkow A (Ed.) Travels in East Africa in the years 1903-1905, 399-418. [In German]

Pax F (1926) The anemones from the Dutch South Polar Expidition from 1901-1903. Dutch South Polar Expedition 1901-1903 18: 3-62. [In German]

Quoy JRC, Gaimard P (1833) Discoveries during the Voyage of the Astrolabe by the King's College during the years 1826, 1827, 1828 and 1829, under the command of M. J. Dumont D’Urville. Tastu, Paris, 390 pp. [In French]

Rafinesque CS (1815) Analysis of Nature and the Universe. Rafinesque, C. S. Palerme, 224 pp. [In German]

Richardson DL, Harriott VJ, Harrison PL (1997) Distribution and abundance of giant sea anemones (Actiniaria) in subtropical eastern Australian waters. Marine and Freshwater Research 48: 59-66. doi: 10.1071/MF96020

Rodríguez E (2012) Another bipolar deep-sea anemone: new species of Iosactis (Actiniaria, Endomyaria) from Antarctica. Helgoländer Marine Research 66: 211-218. doi: 10.1007/ s10152-011-0263-2

Saville-Kent W (1893) The Great Barrier Reef of Australia; Its Products and Potentialities. W. H. Allen \& Co, 387 pp. doi: 10.5962/bhl.title.58247

Schama R, Mitchell M, Solé-Cava AM (2012) Actinia ebhayiensis sp. nov., a new species of sea anemone (Anthozoa: Actiniaria: Actiniidae) from South Africa. Journal of the Marine Biological Association of the United Kingdom 92: 885-894. doi: 10.1017/ S0025315411001305

Scott A, Harrison PL (2007a) Broadcast spawning of two species of sea anemone, Entacmaea quadricolor and Heteractis crispa, that host anemonefish. Invertebrate Reproduction and Development 50: 163-171. doi: 10.1080/07924259.2007.9652241

Scott A, Harrison PL (2007b) Embryonic and larval development of the host sea anemones Entacmaea quadricolor and Heteractis crispa. Biological Bulletin 213: 110-121. doi: $10.2307 / 25066627$

Scott A, Harrison PL (2008) Larval settlement and juvenile development of sea anemones that provide habitat for anemonefish. Marine Biology 154: 833-839. doi: 10.1007/s00227008-0976-1

Stephenson TA (1920) On the classification of Actiniaria. Part I - forms with acontia and forms with a mesogloeal sphincter. Quarterly Journal of Microscopical Science 64: 425-574.

Stephenson TA (1922) On the Classification of Actiniaria. Part III - Definitions connected with the forms dealt with in Part II. Quarterly Journal of Microscopical Science 66: 247-319.

Uchida H, Okamoto K, Fukuda T (1975) Some observations on the symbiosis between anemonefishes and sea-anemones in Japan. Bulletin of the Marine Park Research Stations 1: 31-46.

Uchida H, Soyama I (2001) Sea Anemones in Japanese Waters. TBS, Japan, 157 pp.

Verrill AE (1865) Classification of polyps - Extract condensed from a Synopsis of the Polypi of the North Pacific Exploring Expedition, under Captains Ringgold and Rodgers, U.S.N. Proceedings of the Essex Institute 4: 145-152. 
Verrill AE (1866) On the polyps and echinoderms of New England, with descriptions of new species. Proceedings of the Boston Society of Natural History 10: 333-357.

Verrill AE (1867) Madreporaria [continued]. Communications of the Essex Institute1 5: 33-50.

Verrill AE (1869) Synopsis of the polyps and corals of the North Pacific Exploring Expedition, under Commodore C. Ringgold and Capt. John Rodgers USN from 1853 to (1856) Collected by Dr. Wm. Stimpson, naturalist to the Expedition. Part IV. Actiniaria [Second part]. Proceedings of the Essex Institute 6.

Verrill AE (1899) Descriptions of imperfectly known and new Actinians, with critical notes on other species, II. Brief Contributions to Zoology from the Museum of Yale College. 